\title{
THE CONVENTION ON THE RIGHTS OF PERSONS WITH DISABILITIES AND THE LEGAL CAPACITY OF PERSONS WITH PSYCHOSOCIAL DISABILITIES - CONTEMPORARY CHALLENGES
}

\author{
Izv. prof. dr. sc. Sandra Fabijanić Gagro* \\ Izv. prof. dr. sc. Marissabell Škorić**
}

\author{
UDK 341.231.14-056.26 \\ https://doi.org/10.30925/zpfsr.41.3.5 \\ Ur.: 1. listopada 2020. \\ Pr.: 16. studenoga 2020. \\ Pregledni rad
}

\begin{abstract}
Summary
The first international document to be adopted in the field of human rights protection in the $21^{s t}$ century was the Convention on the rights of persons with disabilities. It imposes on its parties the obligation to create conditions that will enable persons with psychosocial disabilities to finally exercise their rights, will, and preferences on an equal basis with other members of society. The paper is divided into two parts: the first presents the new concept of legal capacity prescribed in Art. 12, in which the role of the state is seen through the commitments to implement faster and more efficient paradigm shifts in the approach to protecting the rights of these persons and the shift from substitute to supported decision-making. The second part deals with the interpretation and application of Art. 12 in the States Parties. Special attention will be paid to the challenges faced by states and how successfully they meet their obligations under the Convention through the elaboration of individual states'reports on the implementation of Art. 12 and the views and recommendations of the Committee for the protection of persons with disabilities.
\end{abstract}

Keywords: Convention on the rights of persons with disabilities; people with psychosocial disabilities; legal capacity; states'reports; substitute and supported decision-making.

* Sandra Fabijanić Gagro, Ph.D., Associate Professor, University of Rijeka, Faculty of Law; fabijani@pravri.hr.

** Marissabell Škorić, Ph.D., Associate Professor, University of Rijeka, Faculty of Law; skoric@ pravri.hr. 


\section{INTRODUCTION}

The Convention on the rights of persons with disabilities ${ }^{1}$ is the first internationally binding instrument that comprehensively regulates the rights of the largest minority group in the world - persons with disabilities. ${ }^{2}$ The CRPD assigns the State Parties with an important and demanding task to ensure that these persons, as all other people, enjoy access to all human rights and fundamental freedoms, with particular emphasis on values such as human dignity and equality, freedom from discrimination, and personal autonomy. Furthermore, the CRPD is associated with some other specificities. First of all, it should be pointed out that, in addition to the representatives of a number of countries and non-governmental organizations, a significant number of persons with disabilities participated in its creation. ${ }^{3}$ According to the chairman of the ad hoc committee, Don McKay, these persons drafted and devised at least $80 \%$ of the text, so that their final contribution to the drafting of the CRPD can be marked as exceptional. ${ }^{4}$ A further specificity of this document is the speed of its preparation and acceptance. Namely, only four years have passed from the beginning of its first draft until the adoption of the final text, which makes these negotiations the shortest ones in history regarding the development of an international human rights instrument. As a special feature, it should be noted that the CRPD was the first international human rights document adopted in the $21^{\text {st }}$ century and that, already on the first day of being opened for signature, it was signed by 81 countries and the EU. ${ }^{5}$ Before that, no human rights document had been accepted at such a rate by such a large number of countries. Initial enthusiasm has continued and, so far, 163 states have signed and 182 ratified the Convention. ${ }^{6}$

1 The Convention on the rights of persons with disabilities (hereinafter: Convention or CRPD) was adopted by UN General Assembly Resolution A/Res/61/106 on 13 December 2006. On the same day, the Optional Protocol to the Convention on the rights of persons with disabilities was adopted. Both documents entered into force in May 2008 and were ratified by the Republic of Croatia in August 2007 (Official Gazette, International Treaties, 6/2007, 5/2008).

2 According to the UN, $15 \%$ of world population or over one billion people live with some form of disability. Disturbing data shows that number has increased almost rapidly in last two decades. Compare data from UN Fact sheet on Person with Disabilities: https://www.un.org/ development/desa/disabilities/resources/factsheet-on-persons-with-disabilities.html

3 Communities of people with disabilities were organized through an informal network known as the International Disability Caucus. It is a coalition composed of 70 international and national organizations of persons with disabilities and related organizations from around the world. In drafting the first text of the CRPD, the working group consulted 222 persons with disabilities from 12 countries on what protection they considered relevant to their own lives. Gerison Lansdown, See Me, Hear Me; A guide to using the UN Convention on the Rights of Persons with Disabilities to promote the rights of children (London: UNICEF, 2009), 20; Mohamed Saidu Kamara et. al., "The United Nations Convention on the Rights of Persons with Disabilities: From the Perspective of Young People", Disability Studies Quarterly 29, No.1 (2009), https://dsq-sds.org/article/view/171.

4 Lansdown, See Me, Hear Me; A guide to using the UN Convention on the Rights of Persons with Disabilities to promote the rights of children, 20.

5 The CRPD is the first international human rights instrument to be ratified by the EU.

6 As of September 2020, only eight UN member states have not ratified the CRPD. See data 
The paper analyzes the impact of the Convention on the position of a group of persons with psychosocial disabilities. According to its Art. 1, persons with disabilities include "those who have long-term physical, mental, intellectual, or sensory impairments, which in interaction with various barriers may hinder their full and effective participation in society on an equal basis with others." Although this definition raises important unsettled questions, it is accepted by the authors and the Committee on the rights of persons with disabilities ${ }^{7}$ that people with psychosocial disabilities (mental illnesses) fall under the CRPD, at least in instances when their mental illness problems are longer-lasting in nature. ${ }^{8}$ The CRPD is particularly important for this group of people because it represents the first international human rights treaty which specifically addresses their issues. Namely, all previously adopted documents relating to persons with psychosocial disabilities were soft law documents and could not impose obligations on states in the field of protecting their human rights. ${ }^{9}$ In addition, although they were intended as a framework for the protection of human rights of persons with psychosocial disabilities, they, in principle, recognized the wide discretion of states in the area of restricting those same rights. ${ }^{10}$ As a result,

available at: https://treaties.un.org/Pages/ViewDetails.aspx?src=IND\&mtdsg_no=IV$15 \&$ chapter $=4$.

7 Committee on the Rights of Persons with Disabilities (hereinafter: the Committee) is the body of independent experts which monitors implementation of the CRPD by the State Parties. For more on the Committee see Katherine Guernsey, "Art 34, Committee on the Rights of Persons with Disabilities", in: The UN Convention on the Rights of Persons with Disabilities: A Commentary, eds. Ilias Bantekas, Michael Ashley Stein and Dimitris Anastasiou (Oxford University Press, 2018), 1012-1037.

8 The Committee expressed its concern at the risk of exclusion of persons who should be protected by the Convention, in particular persons with psychosocial disabilities ('mental illness') or intellectual disabilities. See its first Concluding observations on a State Party report (CRPD/C/TUN/CO/1, 2011, para. 8). Compare George Szmukler, Rowena Dow and John Dawson, „Mental health law and the UN Convention on the rights of persons with disabilities“, International Journal of Law and Psychiatry 37, No. 3 (2014): 245.

9 For example, UN General Assembly adopted The Declaration on the Rights of Mentally Retarded Persons (1971), Principles for the protection of persons with mental illness and the improvement of mental health care (1991) and Standard Rules on the Equalization of Opportunities for Persons with Disabilities (1991). In 1996, the WHO enacted the Mental health care law: Ten basic principles with instructions for their effective implementation in practice.

10 UN General Assembly dedicated in Declaration on the Rights of Mentally Retarded Persons and Principles for the protection of persons with mental illness and the improvement of mental health care that people with mental disabilities were unable of exercising some rights on their own. This approach was strongly criticized. Nicholas Caivano, "Conceptualizing Capacity: Interpreting Canada's Qualified Ratification of Article 12 of the UN Disability Rights Convention", Western Journal of Legal Studies 4, No. 1 (2014): 7; Penelope Weller, "Lost in Translation: Human Rights and Mental Health Law", in: Rethinking Rights-Based Mental Health Laws, eds. Bernadette McSherry and Penelope Weller (Oxford and Portland: Hart Publishing Ltd, 2010), 64; Piers Gooding, "Change and Continuity in Mental Health Law: the Long Road to the UN Convention on the Rights of Persons with Disabilities and its Implications for Mental Health and the Law Today", European Journal of Current Legal Issues 20, No. 3 (2014): 6-7. 
people with mental disabilities were guaranteed respect for human dignity, personal autonomy, independence, equality, and non-discrimination on paper. However, in practice, society saw them primarily as objects to be decided on by others because they themselves were not capable of it. Because of this attitude, people with mental disabilities encountered obstacles that prevented them from fully participating in society as its equal members and have faced numerous violations of their rights in all parts of the world. ${ }^{11}$ The creators of the CRPD recognized the importance of changing society's attitude toward people with mental disabilities and incorporated provisions that insist on the respect for their autonomy and the right to self-determination. The Convention, therefore, does not establish any new, special human rights for people with mental disabilities, but its primary importance lies in the fact that it imposes an obligation on states to create conditions that will enable people with mental disabilities to finally be recognized as equal members of society and given the opportunity to realize their rights and potentials.

This paper aims to highlight the importance of the adoption of the CRPD in relation to persons with psychosocial disabilities and the innovations in regulating their legal status. In this regard, the first part provides a brief overwiev of the new concept of legal capacity prescribed in Art. 12 of the CRPD. The second part of the paper underscores the challenges in the implementation of Art. 12, which developed primarily due to the differences and inconsistencies in the practice of State Parties, analyzed through their reports to the Committee.

\section{OBLIGATION OF THE STATE PARTIES TO IMPLEMENT “THE PARADIGM OF PRESUMED LEGAL CAPACITY" AND CHALLENGES AHEAD}

The late first half of the $20^{\text {th }}$ century had been marked by so-called medical model of disability. That was a period when mental disorders (disability) were treated exclusively as a defect, i.e., damage on the part of an individual who needs appropriate care and assistance, which justifies medical intervention. ${ }^{12}$ The existing legal framework for treating people with mental disabilities was reduced in practice to a mere formalism in which the physicians had wide discretion. This, unfortunately, led to a series of abuses to the detriment of psychiatric patients. ${ }^{13}$ Therefore, it is not surprising that the creators of the CRPD stepped away from this model and accepted other - so called social model of disability. ${ }^{14}$ It assumes that most negative

11 CRPD, Preamble (k).

12 See more in: Deborah Marks, "Models of disability", Disability and Rehabilitation 19, No. 3 (1997): 85-91.

13 Since Winterwerp v. Netherlands case in 1979, numerous violations of fundamental human rights of persons with psychosocial disabilities have been confirmed in cases before the ECtHR. See Peter Bartlett, "Mental disability, the ECHR and the Sustainable Development Goals" in: The Routledge Handbook of International Development, Mental Health and Wellbeing, ed. Laura Davidson (London: Routledge, 2019), 273-290.

14 Mike Oliver, „The social model of disability: thirty years on“, Disability \& Society 28, No. 7 (2013): 1024-1026; Anna Lawson and Mark Priestley, „The social model of disability, Questions 
experiences of people with disabilities are socially conditioned rather than the result of a person's actual physical or mental disorder. Disability is not seen as a person's limitation or impairment, but as a consequence of an inappropriate social response to certain needs of the individual. Removing barriers in society through the adoption on new legislative, educational, cultural, and social policies will ensure the independence and equality of people with disability and give them the opportunity to choose and take control of their own lives. ${ }^{15}$ The greatest contribution of this model is that it has empowered people with disabilities to unite, organize, and insist on the respect for their rights. Supporting the social model, the CRPD emphasizes the realization of the rights of persons with disabilities by referring to a number of areas (e.g., education, training, employment, etc.) in which it is necessary to take appropriate measures to make it happen. Such realization should lead to a greater inclusion of people with mental disabilities in society. Although these ideas are not new, it was only with the Convention's entry into force that their realization became the focus of societal and academic interests.

The guiding principle is that State Parties have a duty to "promote, protect and ensure the full and equal enjoyment of all human rights and fundamental freedoms by all persons with disabilities [including those who require more intensive support], ${ }^{16}$ and to promote respect for their inherent dignity." 17 In order to finally bridge the gap that exists between the prescribed rights of persons with mental disabilities and their implementation in practice, Art. 12 of the CRPD contains several structural features. ${ }^{18}$ The insistence of this provision on the respect of the person's autonomy signifies not only progress in relation to the existing regulations on the matter, but it is the most revolutionary of the new norms articulated in the CRPD. It establishes a "paradigm of presumed legal capacity" 19 and represents "the beating hart" ${ }^{20}$ of the Convention.

The novelties introduced by Art. 12 can be considered through two aspects: a) acceptance of the new concept of legal capacity and b) the necessity to replace the model of substitute decision-making with a new model of supported decisionmaking. In this direction, the (new) obligations assumed by the State Parties, as well as the challenges they face in doing so, should be considered. This section also clearly highlights the divergence in the interpretation of Art. 12 between State Parties and

for law and legal scholarship?", in: Routledge Handbook of Disability Law and Human Rights, eds. Peter Blanck and Eilionóir Flynn (London: Routledge, 2016), 3-15.

15 Peter Bartlett, "The United Nations Convention on the Rights of Persons with Disabilities and Mental Health Law", Modern Law Review 75, No. 5 (2012): 758-760.

16 CRPD, Preamble (j).

17 CRPD, Art. 1.

18 Oliver Lewis, "The Expressive, Educational and Proactive Roles of Human Rights: An Analysis of the United Nations Convention on the Rights of Persons with Disabilities", in: Rethinking Rights-Based Mental Health Laws, eds. Bernadette McSherry and Penelope Weller (Oxford and Portland: Hart Publishing Ltd, 2010), 113.

19 Caivano, Conceptualizing Capacity: Interpreting Canada's Qualified Ratification of Article 12 of the UN Disability Rights Convention, 2.

20 Anna Nilsson, "Who gets to decide? Right to legal capacity for persons with intellectual and psychosocial disabilities", Council of Europe: Commissioner for Human Rights (2012): 14, https://rm.coe.int/16806da5c0. 
the Committee. This was the impetus for the Committee to adopt its first General Comment with a view to clarifying Art. 12. ${ }^{21}$

\subsection{Embracing the new concept of legal capacity}

The creators of the CRPD recognized that the enjoyment of full legal capacity is a fundamental precondition for the realization of all other rights listed in it and prescribed in Art. 12 that all persons with disabilities have the right to recognition everywhere as persons before the law and enjoy the same legal capacity on an equal basis with others in all aspects of life. ${ }^{22}$

However, the CRPD does not define the term legal capacity, and in practice the fact that there is no consensus among the State Parties on what exactly this term represents became noticeable very quickly. It is precisely the controversy over whether it is limited solely to the ability of an individual to be a holder of rights and duties and to be recognized before the law (legal standing) ${ }^{23}$ or whether it includes the ability of an individual to exercise those rights and duties within a particular legal system (legal agency), leads today to different interpretations, and then consequently to different applications of Art. 12 in practice. ${ }^{24}$ Despite the fact that the harmonization of national legislation with the content of Art. 12 was considered crucial for the realization of all other rights guaranteed by the CRPD and its implementation was marked as a special priority, its entry into force and the submission of the first reports to the Committee clearly revealed the different interpretations of Art. 12, ignoring thereby that the CRPD "implies a shift from the substitute decision-making paradigm to one based on supported decision-making." 25

This was the reason for the Committee to adopt General Comment No. 1. It aims to clarify Art. 12 and further emphasizes the need for the recognition of universal legal capacity of all persons in terms of unifying its meaning and finally overcoming different interpretations of Art. $12 .{ }^{26}$ General Comment reaffirms that perceived or actual deficits in the decision-making skills of a person (mental capacity) must not be

21 General Comment No. 1 on Article 12 titled "Equal recognition before the law" (CRPD/C/ GC/1) was adopted by the Commitee on May 19, 2014.

22 CRPD, Art. 12(1) and (2).

23 This may include different actions: e.g., having a birth certificate or applying for a passport, seeking medical assistance, etc.

24 The concept of legal capacity was also discussed during the negotiations for the adoption of the CRPD. See more in: Marianne Schulze, Understanding the UN Convention on the Rights of Persons with Disabilities, A Handbook on the Human Rights of Persons with Disabilities, (New York: Handicap International, 2009), 60-62; Caivano, Conceptualizing Capacity: Interpreting Canada's Qualified Ratification of Article 12 of the UN Disability Rights Convention, 2.

25 Report of the Committee on the Rights of Persons with Disabilities, A/74/55, New York, 2019, para. 62.

26 In Arstein-Kerslake's and Flynn's opinion, this document might be used as a roadmap for State Parties in order to comply with provisions of Article 12, while demanding equal treatment of persons with disabilities. Ana Arstein-Kerslake and Eilionóir Flynn, "The General Comment on Article 12 of the Convention on the Rights of Persons with Disabilities: a roadmap for equality before the law", The International Journal of Human Rights 20, No. 4 (2016): 472. 
used as justification to deny her/his legal capacity. ${ }^{27}$ Denying a person's legal capacity leads to the deprivation of many fundamental rights. ${ }^{28}$ In that moment, a person with psychosocial disability becomes an object, not a subject, incapable of participating in the community on an equal basis with others and to take control over her/his life. Such control is in the hands of other individuals or the state. ${ }^{29}$ Namely, in some European countries, guardians are automatically given power to make decisions on behalf of individuals who have lost their legal capacity. ${ }^{30}$

In order to place persons with psychosocial disability on an equal footing with others, the clear intention of Art. 12 is to abandon the afore-mentioned practices and apply the model of supported decision-making, in which a person has the right and opportunity to express will and preferences, while it is the obligation of a State Party to enable her/him to exercise that right.

\subsection{Necessity of providing access to the requiring support in exercising legal capacity}

Simultaneously with the promotion of the new concept of legal capacity, the CRPD provides that, in the event that an individual is facing any sort of difficulties in decision-making or communicating a decision, the state shall take appropriate measures to provide access to support, which the person may require in exercising legal capacity. ${ }^{31}$ However, since the Convention does not establish a definition of the term support or any specific measures aimed at assisting a person with a disability to exercise her/his legal capacity by making decision(s), a "general misunderstanding"32 of the State Parties on the scope of the CRPD, interpretation, and implementation of Art. 12 have become even more apparent. The General Comment No. 1 aimed to clarify the contentious issues of interpretation of Art. $12,{ }^{33}$ however, the discrepancy

27 See more: General Comment, paras. 9, 10, 13-15, 29(i). For a critical review of the Committee's radical stance of these issues see Marissabell Škorić, "Twenty-first century - beginning of a new era in the protection of human rights of persons with mental health disabilities", Pravni vjesnik 36, No. 1 (2020): 35-38.

28 Such a denial, as well as the consequent substitute decision-making regimes, affect all persons with disabilities, but primarily those with cognitive or psychosocial disabilities. General Comment, paras. 8-9. See also Report of the Committee on the Rights of Persons with Disabilities, A/74/55, New York, 2019, para. 61.

29 Arstein-Kerslake and Flynn, The General Comment on Article 12 of the Convention on the Rights of Persons with Disabilities: a roadmap for equality before the law, 474.

30 Guardian's consent has led to the hospitalization in a psychiatric institution being considered as voluntary in the legal sense despite the absence of consent from the individual concerned. According to an earlier legal solution in Croatia, even a person who was openly expressing her/his opposition to staying in a psychiatric institution being categorized as voluntarily placed because consent to her/his placement was given by a guardian. Velinka Grozdanić and Dražen Tripalo, „Novosti u Zakonu o zaštiti osoba s duševnim smetnjama“, Hrvatski ljetopis za kazneno pravo i praksu 20, No. 2 (2013): 806-807.

31 CRPD, Art. 12(3).

32 General Comment, para. 3.

33 Even without establishing a rigid definion of the term "support," the General Comment provides important clarifications on natures of supported and substitute decision-making, as 
between the views of the Committee expressed in it and the practice of States is still visible.

Namely, in order to prevent the abuses brought about by the institute of guardianship, i.e., the application of the substitute decision-making model in practice, the Convention requires an individualized approach and the Committee continuously insists on it. In this regard, the CRPD imposes an obligation to State Parties to ensure that all measures that relate to the exercise of legal capacity provide for appropriate and effective safeguards to prevent abuse and ensure that measures relating to the exercise of legal capacity respect the rights, will, and preferences of the person with a disability. The CRPD further makes it clear that such safeguards are subject to regular review conducted by a competent, independent, and impartial authority or judicial body. Also, they apply for the shortest time possible. All measures taken must be free of conflict of interest and undue influence, proportional and tailored to the person's circumstances. ${ }^{34}$

It is precisely this part of the CRPD that represents the "core" of Art. 12. At the same time, it has become one of its most controversial and challenging parts that raises many questions of effective and uniform implementation. This provision makes it possible to take into account the ability of an individual to act independently in the exercise of her/his interests and the protection of her/his rights. The intention of the CRPD is that support which a person with a disability receives, is exactly that support. It must ensure the appreciation and respect for the person's right, will, and preference and must not manifest itself as a perception of the person's best interest. ${ }^{35}$ Precisely the exercise of legal capacity that respects the person's rights, will, and preferences presupposes abandoning the model of substitute decision-making and establishing "a paradigm of presumed legal capacity". ${ }^{36}$

However, although states regularly emphasize in their reports that they recognize that persons with disabilities enjoy legal capacity on an equal basis with others, the states' practices show that they still use the guardianship system, considering thereby the existence of circumstances that justify its application. On the other hand, those advocating the need for the exclusive application of a supported decision-making model emphasize the following: if the support provided to a person with a disability, including a person with a very severe form of psychosocial disability, must be expressed in percentages, it may be minimal (e.g., $1 \%$ ) but also maximal (100 \%), provided that the support meets the requirements of the CRPD. In other words, not even maximum support to a person with a severe form of psychosocial disability

well as on the principles required for the effective implementation of Art. 12. Arstein-Kerslake and Flynn, The General Comment on Article 12 of the Convention on the Rights of Persons with Disabilities: a roadmap for equality before the law, 472, 475.

34 CRPD, Art. 12(4).

35 The best interest involves the opinion of the other(s), and - regarding the intention of the CRPD - it is necessary to overcome and abandon that attitude. On the other hand, respect of a person's will and preference includes even the right of a person with a disability to take risk and make her/his own mistakes.

36 Caivano, Conceptualizing Capacity: Interpreting Canada's Qualified Ratification of Article 12 of the UN Disability Rights Convention, 2. 
represents a substitute but rather supported decision-making as long as it expresses the previously established will and preferences of the person. ${ }^{37}$ This is precisely the intention of Art. 12.

In this regard, the obligation of State Parties to replace one model with another requires not only the abolition of substitute decision-making regimes, but also the development of supported decision-making alternatives. ${ }^{38}$ Such a model must provide for the exercise of all the rights set out in the CRPD and must be available to all. The support provided by the Convention does not necessarily exclude the involvement of other people, but gives primacy to a person's will and preferences. It may be provided (on a temporary or permanent basis) by a person close to a person with a disability or by an organized group of people, without such activity being contrary to the provisions of the CRPD. Namely, if a person with a disability decides to transfer their decisionmaking ability to another person of trust, such delegation is not considered to be the substitute decision-making model, but rather decision-making support based on the appointer's will and preferences, and it fully supports the intention of the CRPD. What is important within the supported decision-making model is the fact that the decision is ultimately made by the person with a disability. ${ }^{39}$

\section{STATE PARTIES' ATTITUDE TOWARD THE PROVISION OF ART. 12}

The practical impact of the Convention will undoubtedly depend on the extent to which it is implemented in domestic policies and court decisions. ${ }^{40}$ State parties are obliged to undertake various steps, e.g., the adoption of appropriate legislation, administrative and other measures; modification or abolishment of the existing (discriminatory) laws, regulation, custom and practice; refraining from engaging in any act or practice that is inconsistent with the CRPD, ensuring its implementation and monitoring ${ }^{41}$ etc.

37 What the authors further emphasize as an argument is the fact that the above situation in which a person suffers from such a severe degree of psychosocial disability and in which this support should be expressed in the maximum percentage "is rare when an adequate support system is actually put in place." Schulze, Understanding the UN Convention on the Rights of Persons with Disabilities, A Handbook on the Human Rights of Persons with Disabilities, 60.

38 The very notion of supported decision-making is not defined by the CRPD, but it, in the Committee's view, "encompasses many forms and both informal and formal support arrangements, of varying types and intensity", which diverse from one person to another. General Comment, paras. 17, 18, 28.

39 Aleksandra Korać Graovac and Anica Čulo, "Konvencija o pravima osoba s invaliditetom - novi pristup shvaćanju prava osoba s duševnim smetnjama”, Zbornik Pravnog fakulteta u Zagrebu 61, No. 1 (2011): 76.

40 Steven J. Hoffman, Lathika Sritharan and Ali Tejpar, „Is the UN Convention on the Rights of Persons with Disabilities Impacting Mental Health Laws and Policies in High-Income Countries? A Case Study of Implementation in Canada", BMC International Health and Human Rights 16, No. 1 (2016): 4-5.

41 CRPD, Arts. 4. and 33. 
Yet, from reports submit to the Committee ${ }^{42}$ in accordance with Art. 35, it is clear that states interpret their obligations differently. Most states do not question the application of paras. 1 and 2 of Art. 12. However, at the same time, they support the view that the application of the substitute decision-making model and the system of guardianship is permissible in exceptional circumstances, and that the measures applied are justified as a last resort, which aims to ensure that persons with disabilities are not denied of their rights. There are few reports in which States clearly declare that their domestic legislation is not consistent with the obligation arising from the CRPD and that it contains provisions and measures that need to be reformed and adjusted. ${ }^{43}$ However, even before the submission of reports, the inconsistency of practice and different interpretations of Art. 12 were hinted at through an analysis of the reservations and interpretative declarations made by State Parties upon ratification, formal confirmation, or accession.

In accordance with international law of treaties, reservation represents a unilateral statement of a State Party with the purpose to exclude or modify the legal effect of a certain provision of the treaty in its implementation by a state concerned. In international relations, the reservation always contributes to the difficult implementation of the full text of the convention and to the more complex relations between the State Parties. The CRPD permits reservations which are compatible with its object and purpose. ${ }^{44}$ In relation to the provision of Art. 12, only three countries have entered a reservation and clearly expressed their intention to exclude or modify the legal effect of that provision: Canada, Ireland, and Singapore.

In the reservations made by Canada and Ireland ${ }^{45}$ both states declare with almost identical statements that Art. 12 permits supported and substitute decisionmaking arrangements ,which provide for decisions to be made on behalf of a person, where such arrangements are necessary, in accordance with the law, and subject to appropriate and effective safeguards“ (Ireland), i.e., „in appropriate circumstances and in accordance with the law" (Canada). To the extent to which Art. 12 may be interpreted as requiring the elimination of all substitute decision-making arrangements, both states reserve the right to permit such arrangements in appropriate circumstances and subject them to appropriate and effective safeguards. Additionally, Canada reserves the right not to subject all such measures to regular review by an independent authority, where such measures are already subject to review or appeal. ${ }^{46}$ Ireland has also submitted a separate interpretative statement in application of Art. 12 in which declares its understanding that the CRPD allows for compulsory care or treatment of persons, including measures to treat mental disorders, when circumstances render

42 Reports of State Parties and concluding observations cited and referenced in this paper are available at: https://tbinternet.ohchr.org/SitePages/Home.aspx.

43 See, e.g., Initial reports of State Parties: Serbia, CRPD/C/SRB/1, June 20, 2012, paras. 154, 155.

44 CRPD, Art. 46.

45 Reservations and unilateral declarations are available at: https://treaties.un.org/Pages/ ViewDetails.aspx?src $=$ TREATY \&mtdsg no $=I V-15 \&$ chapter $=4$.

46 For clarification see more in: Initial reports of State Parties: Canada, CRPD/C/CAN/1, February 11, 2014, para. 14. 
treatment of this kind necessary as a last resort, and subject to legal safeguards. ${ }^{47}$

In its initial report, Canada (country that has historically addressed mental health rights through the medical model $)^{48}$ explained its reservation by noting that it allows continuous use of substitute decision-making arrangements in appropriate circumstances and subjecting them to appropriate and effective safeguards. It further stated that a determination of incapacity should only be based on evidence of the individual's actual decision-making ability and that anyone who requires support in exercising their legal capacity should have access to such support. ${ }^{49}$ However, in its Concluding Observations on Canada's Initial report, the Committee expressed its concern about the various circumstances that reflect the discrepancy between the intention of the CRPD and its implementation in practice. The Committee accentuated the increasing number of cases of guardianship over persons with disabilities, the reinforcement of exclusionary tests of legal capacity, and the lack of recognition of supported decision-making in many federal statutes. Moreover, in many Canadian provinces and territories, a substitute decision-maker is permitted to make healthcare decisions for a person who is found to be "incapable" of making her/his own decision. ${ }^{50}$ It is the usual practice of the Committee to propose certain measures in all cases in which it expresses "concern" in relation to the practice set out in the State report. In relation to Canada, the following have been proposed: a) to create a consistent framework for recognizing legal capacity; b) to enable access to the support needed to exercise legal capacity; and c) to take steps for several legislative changes. ${ }^{51}$

The Republic of Singapore emphasized in its reservation that it reserves the right "to continue to apply its current legislative framework in the form of a regular review referred to in Art. 12, para. 4." 52 In an Initial report Singapore clarified its legal framework for empowering persons who lack the mental capacity to make decisions for themselves. Such persons are provided with support to enable them to make as many of their own decisions as possible. Any decisions made on behalf of persons with disabilities must be in their best interest. As in the case of Canada and most of the countries in their reports, Singapore emphasized that the mental capacity of a person is not determined by whether or not she/he has a disability, but rather by her/ his decision-making ability. ${ }^{53}$

Given such a small number of reservations in relation to the total number of State Parties, it could be concluded that, at the time when they were able to formulate a reservation, states did not see anything controversial in Art. 12 and considered

47 Ireland ratified the Convention in March 2018 and an Initial Report is not yet available.

48 Hoffman, Sritharan and Tejpar, Is the UN Convention on the Rights of Persons with Disabilities Impacting Mental Health Laws and Policies in High-Income Countries? A Case Study of Implementation in Canada, 5.

49 Initial Report: Canada, para. 33.

50 Concluding observations on the initial report of Canada, CRPD/C/CAN/CO/1, May 8, 2017, para. 27.

51 Concluding observations: Canada, para. 28.

52 Reservation of Singapore.

53 Initial reports of State Parties: Singapore, CRPD/C/SGP/1, June 30, 2016, para. 162. The Concluding Observations of the Committee on Singapore's report is not yet available. 
their national legislative framework to be fully compliant with the CRPD provision. On the other hand, this is unlikely if we recall that discussions were held during the negotiations on the content of the notion of legal capacity. If we take into account that a significant number of States still apply the model of substitute decision making, yet also emphasize that they strive "to allow people with disabilities to participate in life without restricting their ability to act" 54 or that their anti-discrimination legislation "ensures that persons with disabilities have legal capacity in all areas of life on an equal footing with others, ${ }^{\prime 5}$ it is clear that there is a significant divergence between the views of State Parties on what their obligation is under Art. 12 and the Committee's understanding of how it is necessary to act in the effective implementation of the "paradigm of presumed legal capacity."

It is important to emphasize that states sometimes express the so-called interpretative declarations. They should be clearly distinguished from reservations. Namely, while the purpose of a reservation is the exclusion or modification of the legal effect of some provision(s) of the treaty in question, the purpose of the interpretative declaration is to clarify a state's position or to precisely determine the meaning or scope of an international treaty or some of its provisions ${ }^{56}$ However, in practice, sometimes they represent hidden reservations, ${ }^{57}$ which makes the difference between them unclear and contributes to legal uncertainty. The content of interpretative declarations in relation to the content of Art. 12 also clearly indicates its uneven understanding and application in practice.

Some states have made it clear that their interpretation of Art. 12 does not preclude the application of the substitute decision-making model where necessary. This is the case, for example, with the Netherlands and Australia. Thus, the Netherlands, with a clear emphasis on the principle of equality for all in enjoying legal capacity ${ }^{58}$ declared its understanding of the application of Art. 12 as allowing both models of decisionmaking arrangements in appropriate circumstances and in accordance with the law. Substitute decision-making arrangements are restricted to cases where such measures are necessary, as a last resort, and subject to safeguards..$^{59}$

A very similar statement was made by Australia. ${ }^{60}$ Comparing the content of the reservations given, e.g., by Ireland and Canada with the interpretative declarations of Australia and the Netherlands, it is evident that all states declare the same understanding of Art. 12. According to Australia's Initial Report, the substitute decision-making

54 Initial reports of State Parties: Austria, November 2, 2010, CRPD/C/AUT/1, para. 140.

55 Initial reports of State Parties: Slovakia, CRPD/C/SVK/1, June 26, 2012, para. 93.

56 See more in: Vesna Crnić-Grotić, Pravo međunarodnih ugovora (Rijeka: Pravni fakultet Sveučilišta, 2002), 7-48.

57 For example, if we take into account that the term legal capacity in accordance with Art. 12 presupposes capacity for rights and capacity to act, the interpretative statement of Egypt is nothing but a covert reservation. Namely, under the title "Interpretative declaration made upon signature," Egypt states that it considers that the concept of legal capacity implies the capacity to "acquire rights and assume legal responsibility, but not the capacity to perform under Egyptian law." See: Interpretative declaration made upon signature of Egypt.

58 Initial reports of State Parties: Netherlands, CRPD/C/NLD/1, July 13, 2018, paras. 123-125.

59 Declarations od the Kingdom of Netherlands.

60 Declaration of Australia. 
model "may be necessary as a last resort to ensure that persons with disabilities are not denied access to proper medical treatment because of an inability to assess or communicate their needs and preferences. ${ }^{61}$ In the last Concluding observations with regards to Australia's reports, ${ }^{62}$ the Committee expressed its concern that the regime of substitute decision-making will be maintained and that there is still no detailed and viable framework for supported decision-making in the exercise of legal capacity. It recommended a wide range of activities on the primacy of supported decision-making mechanisms. ${ }^{63}$

A similar interpretation of the scope of Art. 12 is contained in the interpretative statements of Norway and Poland. Namely, Norway - in cases where such measures are necessary, as a last resort and subject to safeguards - considers "the withdrawal of legal capacity or support in exercising legal capacity, and/or compulsory guardianship" to be permissible. In its Initial Report, Norway explained in great detail its position on the compliance of the new national legislation (by adopting the new Guardianship Act) with the provision of Art. 12. Despite the fact that it continues to use the guardianship system, it is given new content and the term "individually tailored guardianship" is introduced. It seeks to emphasize the fact that this is a modern form of help based on respect for integrity, will, and preferences of the individual. ${ }^{64}$ However, repealing the Guardianship Act, which allows for the deprivation of legal capacity based on impairment, ensuring that no person is placed under guardianship, and the consideration of systemic change and replacement of the system of guardianship and all other forms of substitute decision-making, were some of the Committee's recommendations given to Norway. ${ }^{65}$

In submitting its interpretative statement, Poland stated that it interpreted Art. 12 as "allowing the application of the incapacitation, in the circumstances and in the manner set forth in domestic law, as a measure indicated in Art. 12 para. 4, when a person suffering from a mental illness, mental disability or other mental disorder is unable to control her/his conduct." 66 The Committee clearly expressed concern about such an interpretation. The Recommendation given to Poland refers to the necessity of taking measures for the development of a supported decision-making mechanism that respect the autonomy, will, and preferences of persons with disability (starting from the withdrawal of the Interpretative declaration, repeal of all discriminatory legal provisions, etc.). ${ }^{67}$

Estonia has also provided an interpretative declaration on Art. 12 "as it does not forbid to restrict a person's active legal capacity, when such need arises from the

61 Initial reports of State Parties: Australia, CRPD/C/AUS/1, December 3, 2010, para. 55.

62 Concluding observation for the Netherland is not yet available.

63 Concluding observations on the combined second and third periodic reports of Australia, CRPD/C/AUS/CO/ 2-3, October 15, 2019, paras. 24-26.

64 Initial reports of State Parties: Norway, CRPD/C/NOR/1, July 2, 2015, paras. 75-101.

65 Concluding observations on the initial report of Norway, CRPD/C/NOR/CO/1, May 7, 2019, paras. 19-20.

66 Interpretative Declaration made upon ratification of Poland.

67 Concluding observations on the initial report of Poland, CRPD/C/POL/CO/1, October, 29, 2018, paras. 19-20. 
person's ability to understand and direct her/his actions. In restricting the rights of persons with restricted active legal capacity the Republic of Estonia acts according to its domestic laws. ${ }^{\prime 68}$ The report shows that Estonia understands the term legal capacity only as legal standing which cannot be restricted, while the legal agency (capacity to enter independently into valid transaction) of persons with mental illness, mental disability, or another mental disorder or those persons who are permanently unable to understand or direct their actions, may be restricted by a court on the basis of a forensic psychiatric examination about the person's ability to understand her/his actions." ${ }^{69}$

An interesting interpretive statement was made by Venezuela. Namely, it interprets Art. 12, para. 2 in such a way that, in the case of conflict between Art. 12 and any provision of national legislation, the one "that guarantee the greatest legal protection to persons with disabilities, while ensuring their well-being and integral development, without discrimination, shall apply." ${ }^{\text {70 }}$ From its Initial Report it is clear that Venezuela also - despite accepting the term legal capacity as both capacity for rights and capacity to act - puts people with mental or intellectual disability at a disadvantage. Namely, their legal capacity may be exercised through a legal or supervisory guardian and their transactional capacity are limited by the domestic Civil Code. Persons with disabilities that are not mental or intellectual enjoy the full exercise of their legal capacity without any restrictions. ${ }^{71}$

An analysis of State Parties' reports shows that the Committee very clearly emphasizes and encourages the abandonment of the model of substitute decisionmaking and the exclusive application of the model of supported decision-making. In doing so, it does not hesitate to express its concern with the practice of State Parties which: a) are inconsistent with the CRPD inasmuch as they restrict or deny the legal capacity of persons with disabilities completely or partially; b) provide guardianship for persons with psychosocial or intellectual disabilities; c) understand guardianship as a form of support, a perception that is not consistent with the CRPD; d) lack the measures to abolish the denial or restriction of legal capacity, etc. Various recommendations are oriented towards: a) the elimination of all types of guardianship; b) the development and implementation of supported decision-making systems that are respectful for autonomy, will, and preferences of all persons with disabilities: c) raising awareness in society on the right to equal recognition before the law; d) the removal of all practical barriers; e) the establishment of a procedure aimed at restoring full legal capacity for all persons with disabilities, etc.

Given that the Republic of Croatia is also a party to the Convention, this chapter would be incomplete without including it in this brief overview. Croatia submitted its first initial report to the Committee in $2011 .{ }^{72}$ It was clear that guardianship is considered a legitimate and, in certain situations, justified means of protecting persons

68 Declaration of Estonia.

69 Initial reports of State Parties: Estonia, CRPD/C/EST/1, December 4, 2015, paras. 71-73.

70 Declaration of Venezuela.

71 Initial reports of State Parties: Venezuela, CRPD/C/VEN/1, November 2, 2015, paras. 65, 67. The Committee's Concluding observations are not yet available.

72 Initial reports of State Parties: Croatia, CRPD/C/HRV/1, October 27, 2011. 
with disabilities in general, including persons with mental disabilities, whereby the protective role of guardians is clearly emphasized. Considering the Committee recognized that a substitute decision model exists in the legal system of the Croatia, and taking into account the recommendations from General Comment, it is not surprising that the Committee is concerned about its retention. In its 2015 report, ${ }^{73}$ the Committee emphasized that the legislative amendments that were envisaged still consider the best interest of the person as opposed to her/his will and preferences and would maintain a modified regime of substitute decision-making. The Committee's recommendations go in the direction of Croatia's efforts to: a) abolish substitute decision-making model; b) take tangible steps to introduce model of supported decision making; c) introduce legislation to provide a wide range of measures that respect the autonomy, will, and preferences of persons with disabilities; d) involve organizations of persons with disabilities and other relevant stakeholders in legislative and policy processes. ${ }^{74}$

Following the submission of the report in 2011, Croatia adopted new legislative solutions in order to harmonize national legislation with the provisions of the CRPD. As far as the institute of guardianship is concerned, a compromise solution is currently in force. The institute of complete deprivation of legal capacity has been abandoned, but the possibility of partial deprivation of legal capacity has been retained ${ }^{75}$ in the part where this is truly necessary for the protection of the rights of persons with disabilities. It was assessed, namely, that at the time the Law was passed, it was not possible to completely abolish the institute of deprivation of legal capacity because the system could not provide adequate legal protection as well as all other forms of support for persons with disabilities. ${ }^{76}$ Therefore, the institute of partial deprivation of legal capacity was retained, and a legal obligation to respect the previously stated views and wishes of the person was introduced. But, unfortunately, the legislator has not been consistent in terms of imposing an obligation to respect the views and wishes of a person with a disability. Namely, it prescribed that the guardian is obliged to accept the wishes and personal views of the ward unless it is contrary to her/his wellbeing. In this way, in fact, it reduced the person with a disability to an object that someone else decides on, and significantly deviated from the requirements and spirit of the Convention.

73 Concluding observations on the initial report of Croatia, Equal recognition before the law (art.12), CRPD/C/HRV/CO/1, May 15, 2015.

74 The next report of the Republic of Croatia is expected in the second half of 2021. Concluding observations: Croatia, paras. 17, 18, 58.

75 Deprivation of legal capacity and the establishment of guardianship protection is a final measure, before the adoption of which the protection of a person with a disability must be provided by other means and measures if the circumstances allow it. Family Law, Official Gazette, 103/2015; 98/2019; 47/2020, Art. 233. For a critical review of the new solutions see Nenad Hlača, "Status osoba lišenih poslovne sposobnosti u novom hrvatskom zakonodavstvu", in: Zbornik radova, Četvrti međunarodni naučni skup Dani porodičnog prava, "Pravna zaštita odraslih osoba", ed. Suzana Bubić (Mostar: Pravni fakultet Univerziteta Džemal Bijedić, 2016): 103-118.

76 Final draft of the Family Law, Zagreb, September 2015, p. 176-177, 253-256. See also Irena Majstorović and Ivan Šimović, „Opseg lišenja poslovne sposobnosti kao pretpostavka zaštite prava i dostojanstva osoba s invaliditetom“, Ljetopis socijalnog rada 25, No. 1 (2018): 69-75. 
In addition to Family Law, the new Act on the Protection of Persons with Mental Difficulties was adopted in 2014, after the submission of Croatia's initial report. Art. 12 of this Act prescribes that deprivation of legal capacity does not automatically entail inability to give consent. Namely, before applying any medical procedure or placing a person in a psychiatric institution, it is necessary to determine whether the person deprived of legal capacity is able to make her/his own decision and to give consent for medical intervention. If such ability is established, that decision - despite the person being deprived of legal capacity - will be taken as relevant. It can be concluded that legislator made an important step towards strengthening the model of supported decision-making by prescribing such obligation that directly affects person's health and integrity. In addition, the Act introduced the institute of a binding statement (anticipated orders) that allows any adult to authorize a person of trust who will on her/his behalf be able to give or deny consent to certain medical procedures when she/he is not longer able to give or deny such consent. In this way, respect for person's wishes is ensured even at the moment when she/he is unable to express them due to the mental disorders. ${ }^{77}$

However, despite these shifts, Croatian normative framework is still based on a modified model of substitute decision-making and allows partial deprivation of legal capacity. In accordance with the General Comment No. 1 - this leads to a denial of legal capacity and incompatibility with Art. 12 of the Convention.

\section{CONCLUSION}

The Convention was adopted in a short period of time, celebrated as the first human rights document of the $21^{\text {st }}$ century and widely accepted by almost all UN members. However, the fact that an international document is so widely accepted must not reinforce a (false) perception of satisfaction based only on the apparent protection of fundamental human rights. Namely, it is evident that the application of the Convention at national levels, especially with regards to the application of Art. 12, remains a specific challenge. Despite the clear intention of Art. 12 and expectations that the states' practice will encourage a faster shift from the substitute decision-making paradigm to the supported decision-making, this did not happen. The prevalence of substitute decision-making in legislation and practice is still evident from the reports submitted by states to the Committee. It is obvious that states are reluctant to change their legislation asserting at the same time it is compatible with the provisions of the CRPD. The existence of the institute of guardianship and substituted decision-making in their national legislations was mostly justified by the existence of extreme cases (e.g., when a person is in a coma). In doing so, they have completely lost sight of the fact that a number of studies, as well as the practice of the ECtHR, point to numerous abuses of the institution of guardianship, which has often resulted in serious violations of the fundamental human rights of persons under guardianship. It is precisely this

77 See Arts. 68-73 of the Act on the Protection of Persons with Mental Difficulties. The Family Act also prescibed anticipated orders. For a critical review see Hlača, Status osoba lišenih poslovne sposobnosti u novom hrvatskom zakonodavstvu, 106-107. 
reality in which abuses of the rights of persons with psyschosocial disabilities cannot be considered as exceptions related to extreme cases due to their frequency, which is why the Convention's creators insisted on establishing a mechanism to ensure respect for the autonomy and self-determination of these persons.

In addition, it is unquestionable that the intention of the Convention's creators is to strive to determine the previously expressed attitudes and wishes of a person even in such extreme cases, and not to lightly resort to substituted decision-making. It is clear that the further application of the substituted decision-making model calls into question the achievement of the Convention's purpose. Therefore, only further efforts to strengthen the rights of people with mental disabilities can result in a true paradigm shift in the perception and treatment of people with disabilities and the recognition that people with disabilities truly enjoy legal capacity on an equal basis with others in all aspects of life. It is obvious that the paradigm established by Art. 12 presupposes and requires changes which - as the current practice shows - are not easily achievable. The activities that can jointly enhance the improvement of the position of persons with disabilities are ensuring an effective implementation of support measures that will enable the respect and realization of rights, will, and preferences of persons with psychosocial disabilities; ensuring a professional staff capable of providing adequate support; encouraging efforts to overcome stereotypes, prejudices, and harmful practices, etc. All of these actions could also encourage a faster and more effective turn from the substitute decision-making to the supported decision-making model.

The efforts of individual states to harmonize their legislation with the provisions of the CRPD give reason for some optimism. The abandonment of the institute of complete deprivation of legal capacity, introduction of a legal obligation to respect previously expressed wishes and preferences of persons with mental disorders, introduction of anticipated orders into national legal systems, are small but significant steps towards creating a society in which people with psychosocial disabilities will finally be accepted as equal members of the community with the right to make their own choices. Society's efforts must continue to go in that direction.

\section{BIBLIOGRAPHY}

1. Arstein-Kerslake, Ana and Eilionóir Flynn. "The General Comment on Article 12 of the Convention on the Rights of Persons with Disabilities: a roadmap for equality before the law". The International Journal of Human Rights 20, 4 (2016): 471-490.

2. Bartlett, Peter. „Mental disability, the ECHR and the Sustainable Development Goals”. In: The Routledge Handbook of International Development, Mental Health and Wellbeing, ed. Laura Davidson, 273-290. London: Routledge, 2019.

3. Bartlett, Peter. "The United Nations Convention on the Rights of Persons with Disabilities and Mental Health Law", Modern Law Review 75, 5 (2012): 752-778.

4. Caivano, Nicholas. "Conceptualizing Capacity: Interpreting Canada's Qualified Ratification of Article 12 of the UN Disability Rights Convention". Western Journal of Legal Studies 4, 1 (2014): 1-24.

5. Committee on the Rights of Persons with Disabilities, General Comment no 1: Article 12: Equal recognition before the law, CRPD/C/GC/1, 19 May 2014. 
6. Convention on the Rights of Persons with Disabilities, The Official Gazette, International Treaties, 67/2007, 5/2008.

7. Crnić-Grotić, Vesna. Pravo međunarodnih ugovora. Rijeka: Pravni fakultet Sveučilišta, 2002.

8. Gooding, Piers. "Change and Continuity in Mental Health Law: the Long Road to the UN Convention on the Rights of Persons with Disabilities and its Implications for Mental Health and the Law Today". European Journal of Current Legal Issues 20, 3 (2014): 1-24

9. Grozdanić, Velinka and Dražen Tripalo. „Novosti u Zakonu o zaštiti osoba s duševnim smetnjama“. Hrvatski ljetopis za kazneno pravo i praksu 20, 2 (2013): 795-820.

10. Guernsey, Katherine. "Art 34, Committee on the Rights of Persons with Disabilities". In: The UN Convention on the Rights of Persons with Disabilities: A Commentary, eds. Ilias Bantekas, Michael Ashley Stein and Dimitris Anastasiou, 1012-1037. Oxford University Press, 2018.

11. Hlača, Nenad. "Status osoba lišenih poslovne sposobnosti u novom hrvatskom zakonodavstvu". In: Zbornik radova, Četvrti međunarodni naučni skup Dani porodičnog prava, "Pravna zaštita odraslih osoba", ed. Suzana Bubić. 103-118. Mostar: Pravni fakultet Univerziteta Džemal Bijedić, 2016.

12. Hoffman, Steven J., Lathika Sritharan and Ali Tejpar. „Is the UN Convention on the Rights of Persons with Disabilities Impacting Mental Health Laws and Policies in High-Income Countries? A Case Study of Implementation in Canada", BMC International Health and Human Rights 16, 1 (2016): 1-18.

13. Kamara, Mohamed Saidu, Yellamma Gangadhar, Paybeyee D. Daintowon and Ranjana Chandralal. "The United Nations Convention on the Rights of Persons with Disabilities: From the Perspective of Young People”. Disability Studies Quarterly 29, 1 (2009), https:// dsq-sds.org/article/view/171/171.

14. Korać Graovac, Aleksandra and Anica Čulo. "Konvencija o pravima osoba s invaliditetom - novi pristup shvaćanju prava osoba s duševnim smetnjama”. Zbornik Pravnog fakulteta u Zagrebu 61, 1 (2011): 65-109.

15. Lansdown, Gerison. See Me, Hear Me; A guide to using the UN Convention on the Rights of Persons with Disabilities to promote the rights of children. London: UNICEF, 2009.

16. Lawson, Anna and Mark Priestley. „The social model of disability, Questions for law and legal scholarship?“. In: Routledge Handbook of Disability Law and Human Rights, eds. Peter Blanck and Eilionóir Flynn, 3-15. London: Routledge, 2016.

17. Lewis, Oliver. "The Expressive, Educational and Proactive Roles of Human Rights: An Analysis of the United Nations Convention on the Rights of Persons with Disabilities". In: Rethinking Rights-Based Mental Health Laws, eds. Bernadette McSherry and Penelope Weller, 97-128. Oxford and Portland: Hart Publishing Ltd, 2010.

18. Majstorović, Irena and Ivan Šimović. „Opseg lišenja poslovne sposobnosti kao pretpostavka zaštite prava i dostojanstva osoba s invaliditetom“. Ljetopis socijalnog rada 25, 1 (2018): 65-84.

19. Marks, Deborah. "Models of disability". Disability and Rehabilitation 19, 3 (1997): 8591.

20. Nilsson, Anna. "Who gets to decide? Right to legal capacity for persons with intellectual and psychosocial disabilities". Council of Europe: Commissioner for Human Rights (2012): 1-23, https://rm.coe.int/16806da5c0.

21. Oliver, Mike. „The social model of disability: thirty years on“. Disability \& Society 28,7 (2013): 1024-1026.

22. Schulze, Marianne. Understanding the UN Convention on the Rights of Persons with Disabilities, A Handbook on the Human Rights of Persons with Disabilities. New York: Handicap International. 2009. 
23. Szmukler, George, Dow, Rowena and Dawson, John. „Mental health law and the UN Convention on the rights of persons with disabilities". International Journal of Law and Psychiatry 37, 3 (2014): 245-252.

24. Škorić, Marissabell. "Twenty-first century - beginning of a new era in the protection of human rights of persons with mental health disabilities". Pravni vjesnik 36, 1 (2020): 27-45.

25. Weller, Penelope. "Lost in Translation: Human Rights and Mental Health Law". In: Rethinking Rights-Based Mental Health Laws, eds. Bernadette McSherry and Penelope Weller, 51-72. Oxford and Portland: Hart Publishing Ltd, 2010.

List of reports submitted by state parties under art 35 of the Convention:

1. Australia, CRPD/C/AUS/1, December 3, 2010 (June 7, 2012)

2. Austria, CRPD/C/AUT/1, November 2, 2010 (October 10, 2011)

3. Croatia, CRPD/C/HRV/1, October 27, 2011 (May 7, 2013)

4. Canada, CRPD/C/CAN/1, February 11, 2014 (July 7, 2015)

5. Estonia, CRPD/C/EST/1, December 4, 2015 (October 3, 2017)

6. Netherlands, CRPD/C/NLD/1 July 13, 2018 (March 6, 2019)

7. Norway, CRPD/C/NOR/1 July 2, 2015 (December 7, 2015)

8. Serbia, CRPD/C/SRB/1 June 20, 2012 (September 29, 2014)

9. Singapore, CRPD/C/SGP/1, June 30, 2016 (November 16, 2018)

10. Slovakia, CRPD/C/SVK/1 June 26, 2012 (September 24, 2014)

11. Venezuela, CRPD/C/VEN/1, November 2, 2015 (October 6, 2017) 


\section{Sandra Fabijanić Gagro* \\ Marissabell Škorić***}

Sažetak

\section{KONVENCIJA O PRAVIMA OSOBA S INVALIDITETOM I POSLOVNA SPOSOBNOST OSOBA S DUŠEVNIM SMETNJAMA - SUVREMENI IZAZOVI}

Prvi međunarodni dokument koji je na polju zaštite ljudskih prava usvojen u 21. stoljeću bila je Konvencija o pravima osoba s invaliditetom. Ona svojim strankama nalaže obvezu stvaranja uvjeta koji će omogućiti da osobe s duševnim smetnjama konačno ostvare svoja prava, volju i sklonosti na ravnopravnoj osnovi s ostalim članovima društva. Rad je podijeljen u dva dijela: u prvom dijelu izlaže se novi koncept poslovne sposobnosti propisan u čl. 12. Konvencije u kojem se uloga države sagledava kroz preuzete obveze realizacije brže i učinkovitije promjene paradigme u pristupu zaštiti prava ovih osoba te pomaka od zamjenskog ka potpomognutom odlučivanju. Drugi dio rada bavi se tumačenjem i primjenom čl. 12 u državama strankama. S kojim se izazovima države pritom susreću i koliko uspješno udovoljavaju obvezama iz Konvencije, u radu se analizira kroz razradu izvješća pojedinih država o implementaciji čl. 12. te stavova i preporuka Odbora za zaštitu osoba s invaliditetom.

Ključne riječi: Konvencija o pravima osoba s invaliditetom; osobe s duševnim smetnjama; poslovna sposobnost; izvješća država stranaka, zamjensko i potpomognuto odlučivanje.

Zussamenfassung

\section{BEHINDERTENRECHTSKONVENTION UND GESCHÄFTSFÄHIGKEIT DER MENSCHEN MIT GEISTIGER BEHINDERUNG - DIE NEUSTEN HERAUSFORDERUNGEN}

Das erste völkerrechtliche Instrument im Bereich des Menschenrechtsschutzes das im 21. Jahrhundert verabschiedet wurde ist die Behindertenrechtskonvention. Die Konvention verpflichtet ihre Parteien jene Umstände zu schaffen, welche

* Dr. sc. Sandra Fabijanić Gagro, izvanredna profesorica, Sveučilište u Rijeci, Pravni fakultet; fabijani@pravri.hr.

** Dr. sc. Marissabell Škorić, izvanredna profesorica, Sveučilište u Rijeci, Pravni fakultet; skoric@ pravri.hr. 
Menschen mit geistiger Behinderung ihre Rechte, Willen und Neigungen geltend zu machen ermöglichen, und zwar auf gleicher Grundlage wie allen anderen Gesellschaftsmitgliedern. Dieser Beitrag ist in zwei Teile gegliedert: im ersten wird der neue Begriff der Geschäftsfähigkeit nach Maßgabe Art. 12 der Konvention aufgezeigt, in welchem die Rolle des Staates aus der Perspektive der übernommenen Pflichten der Realisierung einer schnellen und wirkungsvollen Änderung des Zugangs zum Schutz der Behindertenrechte, und des Voranschreitens von stellvertretender zur unterstützen Entscheidungsfindung. Der zweite Teil befasst sich mit der Auslegung und Anwendung des Art. 12 in Konventionsstaaten. Ausgehend von den Berichten einzelner Staaten zur Implementierung des Art. 12 und Ansichten und Empfehlungen des Ausschusses für den Schutz von Behinderten wird auf die Herausforderungen, mit welchen sich die Staaten auseinandersetzen müssen, hingewiesen und darüber hinaus erläutert, mit welchem Erfolg die Staaten die Konventionsforderungen erfüllen.

Schlüsselwörter: Behindertenrechtskonvention; Personen mit geistiger Behinderung; Geschäftsfähigkeit; stellvertretende Entscheidungsfindung; unterstützte Entscheidungsfindung.

Riassunto

\section{LA CONVENZIONE SUI DIRITTI DELLE PERSONE CON DISABILITÀ E LA CAPACITÀ GIURIDICA DELLE PERSONE CON DISABILITÀ PSICOSOCIALI - SFIDE CONTEMPORANEE}

Il primo documento internazionale adottato nel campo della protezione dei diritti umani nel XXI secolo fu la Convenzione sui diritti delle persone con disabilità. Essa impone alle parti l'obbligo di creare le condizioni che finalmente permetteranno alle persone con disabilità psicosociali di esercitare i loro diritti, la loro volontà e le loro preferenze nel rispetto dell'uguaglianza di tutti i membri della società. Il lavoro è suddiviso in due parti: la prima presenta il nuovo concetto di capacità giuridica prescritta nell' art. 12, nel quale il ruolo dello stato è percepito tramite qli impegni intrapresi nell'implementazione per un cambiamento di paradigma più veloce e più efficace nell'aproccio della protezione dei diritti di queste persone e per uno spostamento dal processo decisionale sostitutivo a quello supportato. La seconda parte tratta l'interpretazione e l'applicazione dell'art. 12 negli Stati membri. Un'attenzione speciale sarà data alle sfide affrontate dagli stati e con quanto successo essi rispettino gli obblighi imposti ai sensi della Convenzione tramite l'elaborazione dei rapporti dei singoli stati nell'implementazione dell'art. 12 e le prospettive e le raccomandazioni della Commissione per la protezione delle persone con disabilità. 
Parole chiave: Convenzione sui diritti delle persone con disabilità; persone con disabilità psicosociali; capacità giuridica; processo decisionale sostitutivo; processo decisionale supportato. 